\title{
Dopamine D4 Receptor Gene Polymorphisms and Neuroleptic Response in Schizophrenia
}

\author{
Hai-Gwo Hwu, Chen-Jee Hong, Yi-Ling Lee, Ping-Chuan Lee, and Sandy F.C. Lee
}

Background: Dopamine D4 receptor (DRD4) gene polymorphisms are associated with various pharmacologic activities. This study investigated whether polymorphisms of 48-bp tandem repeats in the exon 3 of the DRD4 gene are related to neuroleptic response.

Methods: The neuroleptic response at the acute stage of schizophrenia was assessed in 80 (48 men, 32 women) schizophrenic patients. The negative symptoms at remission were also rated. DRD4 genotype was established using the polymerase chain reaction. Patients with genotypes containing an allele with only two repeats (2-2, 2-3, $2-4,2-6)$ were assigned to group I $(\mathrm{n}=38)$. Those homozygous for four 48-bp repeats were assigned to group II $(\mathrm{n}=42)$.

Results: Thirteen (34.2\%) of the 38 group I subjects and $26(61.9 \%)$ of the 42 group II subjects had good neuroleptic response during acute stage treatment $\left(\chi^{2}=6.12\right.$, $d f=1, \mathrm{p}<.02)$. In remission, the rates of negative symptoms of blunt affect, avolition, and global negative rating were higher in group I than in group II. This was more prominent in men than in women.

Conclusions: The presence of homozygous four 48-bp repeats in both alleles in exon 3 of the DRD4 gene is associated with good neuroleptic response during acute treatment, and with a lower prevalence of negative symptoms at remission, especially in male schizophrenic patients. Biol Psychiatry 1998;44:483-487 (C) 1998 Society of Biological Psychiatry

Key Words: Dopamine, dopamine D4 receptor, receptor gene, neuroleptic response, schizophrenia, negative symptoms

From the Department of Psychiatry, College of Medicine, National Taiwan University, Taipei, Taiwan (HGH, YLL, PCL); Department of Psychiatry, Veterans General Hospital Taipei, Taipei, Taiwan (CJH); College of Medicine, National Yang-Ming University, Taipei, Taiwan $(\mathrm{CJH})$; and Provincial Taoyuan Mental Hospital, Taoyuan, Taiwan (SFCL).

Address reprint requests to Hai-Gwo Hwu, MD, Department of Psychiatry, National Taiwan University Hospital, No. 7 Chung-Shan South Road, Taipe 100, Taiwan

Received April 21, 1997; revised April 8 1998; accepted April 9, 1998.

\section{Introduction}

$\mathrm{T}$ The dopamine D4 receptor (DRD4) gene has been cloned and localized to the tip of the short arm of chromosome 11 (Gelernter et al 1992). The structural and pharmacologic characteristics of DRD4 are similar to those of the D2 and D3 receptors (Van Tol et al 1991). Genetic polymorphisms of the 48-bp repeat in exon 3 of the DRD4 gene have been studied for possible association and/or linkage with schizophrenia (Barr et al 1993; Shaikh et al 1994; Macciardi et al 1994; Maier et al 1994; Daniels et al 1994; Petronis et al 1995; Hong et al 1997). All these studies showed negative results, indicating that DRD4 was not related to genetic etiology of schizophrenia.

The neuroleptic response of schizophrenia has been thought to be due to the blocking effect of neuroleptics on the D2 receptor and related receptor families (Seeman and Lee 1975). Atypical neuroleptics, such as clozapine, were found to have a higher affinity for the D4 receptor than the D2 or D3 receptors (Van Tol et al 1991). The repeat number of a 48-bp sequence expressed in the third cytoplastic loop of DRD4 affects the pharmacologic activities of this receptor (Iversen 1992). Variants with a greater number of repeats have higher affinity for clozapine and spiperone (Van Tol et al 1991). The relationship of DRD4 gene polymorphisms and clozapine treatment response in refractory schizophrenic patients has been studied, and controversial results have not yet been resolved (Shaikh et al 1993, 1995; Rao et al 1994; Kennedy 1994; Kennedy et al 1995; Rietschel et al 1996; Kohn et al 1997). This allele-related pharmacologic variation suggests that polymorphisms of the DRD4 gene might be related to the pathophysiological mechanism mediating the neuroleptic treatment response in the acute state of schizophrenia.

The density of $\mathrm{D} 4$ receptors is higher in the striatum of schizophrenic patients than in that of normal subjects (Seeman et al 1993). Because of the complex link (Seeman et al 1989) interactions (Meltzer 1995) between different dopamine receptors through the G-protein system, and the increased density of DRD4, it is reasonable to investigate a possible relationship between neuroleptic treatment response in schizophrenia and polymorphisms of the DRD4 
gene. Neuroleptic response has been studied under the dopamine hypothesis (Bowers 1991). A group with good neuroleptic response was found to have a higher pretreatment homovanillic acid level (Bowers 1991; Chang et al 1993). Different pharmacologic mechanisms or different subtypes of patients were studied based on this kind of pharmacologic study (Chang et al 1993). The real nature is still unknown. In this study, we examined whether the neuroleptic response of schizophrenic patients was related to variations of the number of 48-bp repeats in exon 3 of the DRD4 gene that encodes the third cytoplasmic loop of the D4 receptor.

\section{Methods and Materials}

Eighty (48 men, 32 women) schizophrenic patients from community treatment settings of the Department of Psychiatry, National Taiwan University and an affiliated hospital, the Provincial Taoyuan Psychiatric Hospital, were recruited. Written informed consent was obtained prior to study. The clinical diagnosis was ascertained using the Psychiatrist Diagnostic Assessment method (Hwu and Yang 1987), following DSMIII-R (American Psychiatric Association 1987) criteria of schizophrenia. The data from patient charts and clinical interviews were combined for final diagnostic assessment. The mean age of onset of nonspecific symptoms was 20.7 years; the mean age of onset of severe impairment in social function was 22.4 years. Twentysix percent of the patients had received $\leq 9$ years of education, $46 \%$ had received $10-12$ years, and $28 \%$ had received $>12$ years. The mean dose of neuroleptic medication for acute stage treatment in the study hospitals was 1150 (SD 755) mg/day of chlorpromazine equivalent dose. The acute treatment response was assessed based on patient records at discharge and clinical interviews. In assessing the degree of response, positive symptoms of delusion, hallucination, bizarre behavior, and thought process/form disorders were rated as 0-3 (absence to marked), based on the vividness and frequency of these symptoms, and also their influence on social function. If no positive symptom (rated 0) was present after acute stage treatment, the treatment response was regarded as good. If any positive symptom (rated 1-3) remained, the response was considered poor. The interrater reliability test for the assessment method of this rating scale revealed a Spearman rank correlation coefficiency of 1.0 (Hwu 1994).

The clinical psychopathological symptoms were rated at remission, using a Chinese positive and negative symptom rating scale (Hwu 1994), which was composed of four positive symptom items (delusion, hallucination, unusual behavior, and thought process/form disorders) and four negative symptom items (blunt affect, avolition, alogia, and asociality), following the definition of Andreasen (1984a, 1984b). The positive and negative symptoms were rated on a 6-point scale, ranging from 0 to 5 (degree of severity of symptoms). The interrater reliability test showed a satisfactory Spearman rank correlation coefficient of .73-.92 (Hwu 1994). A positive symptom was considered to be present if its rating was above 0 . A negative symptom rating of 1 was considered mild and not of clinical significance. Thus, a negative symptom was considered to be present if its rating was $\geq 2$.

The social function of schizophrenic patients was assessed using a community life scale (Hwu 1991). The interrater reliability was satisfactory, as shown by an intraclass correlation coefficient of .67-.95 (Hwu et al 1987). The social function scale was composed of four dimensions of daily activity: achievement, interpersonal relationships, daily time arrangement, and daily family life function. Each dimension was rated 1-7, ranging from the worst (score 1) to the best (score 7). A score of 4 was considered marginal.

Genomic DNA isolated from lymphocytes was analyzed by polymerase chain reaction (PCR) with oligodeoxynucleotide primers specific for part of the D4 sequence (Shaikh et al 1993). Each PCR was done in a $25-\mu \mathrm{L}$ mixture that contained 50 $\mathrm{mmol} / \mathrm{L} \mathrm{KCl}, 10 \mathrm{mmol} / \mathrm{L}$ Tris- $\mathrm{HCl}$ ph $8.3,0.5 \mathrm{mmol} / \mathrm{L} \mathrm{MgCl}_{2}$, $10 \%$ dimethylsulphoxide (DMSO), $200 \mu \mathrm{mol} / \mathrm{L}$ each of deoxyadenosine triphosphate, deoxythymidine triphosphate, and deoxycytidine triphosphate, $50 \mu \mathrm{mol} / \mathrm{L}$ of deoxyguanosine triphosphate, $150 \mu \mathrm{mol} / \mathrm{L}$ of 7 -deazaguanosine, $0.5 \mu \mathrm{mol} / \mathrm{L}$ of each primer, $100 \mathrm{ng}$ template DNA, and $0.6 \mathrm{U}$ of Dynazyme (Finnzymes oy, Espoo, Finland). This mixture was denatured at $95^{\circ} \mathrm{C}$ for $5 \mathrm{~min}$, followed by 30 cycles of amplification $\left(90^{\circ} \mathrm{C}, 1\right.$ $\min ; 52^{\circ} \mathrm{C}, 1 \mathrm{~min} ; 72^{\circ} \mathrm{C}, 2 \mathrm{~min}$ ), and elongation at $72^{\circ} \mathrm{C}$ for 5 min. PCR products were detected by $2 \%$ ethidium-bromide stained agarose gel electrophoresis and ultraviolet photography.

Patients homozygous for the two 48-bp repeat (2-2), as well as those with two-repeat allele and one three (2-3), one four (2-4), or six (2-6) repeat allele were classified as group I. Patients homozygous for the four 48-bp repeat allele were classified as group II. Differences between groups were tested using the chi-square test for nonparametric data, and the independent $t$ test for parametric data. The level of statistical significance was set at $p<.05$. The statistical analysis was done using the SPSS PC+ package (Norusis 1990).

\section{Results}

Of the 80 study subjects, 38 (48\%) were group I and 42 (32\%) were group II. The genotypes of the group I patients were 2-2 (3 cases), 2-3 (1 case), 2-4 (33 cases), and 2-6 (1 case). There were $22(46 \%)$ men in group I and $26(54 \%)$ in group II. Women were evenly distributed among group I and group II. Sixteen women $(50 \%)$ belonged to each group. There were no differences between groups in educational level, economic status of the family, mean dose of neuroleptic medication, mean age of onset of nonspecific symptoms (20.3 years old versus 21.1 years), or mean age of onset of severe functional impairment (22.5 years old versus 22.4 years).

Group II patients had a significantly higher rate of good neuroleptic response during acute stage treatment than group I patients $\left(\chi^{2}=6.12, \mathrm{df}=1, p<.02\right)$ (Table 1$)$. 
Table 1. Comparison of Neuroleptic Response in Schizophrenic Patients with Different Repeat Numbers of the DRD4 Gene 48-bp Repeat

\begin{tabular}{|c|c|c|c|}
\hline $\begin{array}{l}\text { Neuroleptic } \\
\text { response }\end{array}$ & Group I $(\%)^{a}$ & Group II $(\%)^{b}$ & Statistics \\
\hline Total cases & & & $\chi^{2}=6.12$ \\
\hline Good & $13(34.2)$ & $26(61.9)$ & $\mathrm{df}=1$ \\
\hline Poor & $25(65.8)$ & $16(38.1)$ & $p<.02$ \\
\hline Men & & & $\chi^{2}=5.99$ \\
\hline Good & $5(22.7)$ & $15(57.7)$ & $\mathrm{df}=1$ \\
\hline Poor & $17(77.3)$ & $11(42.3)$ & $p<.02$ \\
\hline Women & & & $\chi^{2}=1.17$ \\
\hline Good & $8(50.0)$ & $11(68.8)$ & $\mathrm{df}=1$ \\
\hline Poor & $8(50.0)$ & $5(31.3)$ & $p<.30$ \\
\hline
\end{tabular}

${ }^{a}$ Group I genotypes include one allele with two 48-bp repeats and the other with $2,3,4$, or 6 repeats.

${ }^{b}$ Patients with group II genotype were homozygous for four 48-bp repeats.

This difference was also significant among men, but not women; however, in group II, there was a tendency for the women to have a higher rate of good response.

In remission, group I patients had a higher rates of negative symptoms, although the difference was not statistically significant (Table 2). This tendency was more prominent in the men. Differences between groups in the items of blunt affect, avolition, and global negative rating reached statistical significance in men; in women, there was no difference. No differences in the prevalence of positive symptom items were found.

The social function scores tended to be lower in group I patients, although the difference was not statistically significant (Table 3). The differences between groups in achievement and time arrangement nearly reached statistical significance.
Table 3. Mean Social Function Assessment in Schizophrenic Patients with Different Repeat Numbers of the DRD4 Gene 48-bp Repeat

\begin{tabular}{lcc}
\hline Social function assessment & Group I (SD) ${ }^{a}$ & Group II (SD) $^{b}$ \\
\hline Achievement score & $2.7(1.8)$ & $3.4(1.6)^{c}$ \\
Interpersonal relationship score & $3.2(1.4)$ & $3.7(1.3)$ \\
Time arrangement score & $2.9(1.7)$ & $3.6(1.6)^{c}$ \\
Family life score & $3.1(1.6)$ & $3.7(1.5)$ \\
\hline \multicolumn{2}{l}{${ }^{a}$ Group I genotypes include one allele with two 48-bp repeats and the other with } \\
$2,3,4$, or 6 repeats. \\
$\quad{ }^{b}$ Patients with group II genotype were homozygous for four 48-bp repeats. \\
$\quad{ }^{c} p<.10$.
\end{tabular}

\section{Discussion}

This study revealed that patients with DRD4 genotype (4-4) had a higher rate of good neuroleptic response than group I patients (genotypes 2-2, 2-3, 2-4, and 2-6) during the acute stage treatment of schizophrenia. Group I was composed of various genotypes, with one allele having two repeats of the 48-bp tandem unit; the other allele had two, three, four, or six 48-bp tandem repeats. The only patient with genotype 2-6 had a good neuroleptic response. While this patient belonged to group I, he might be considered as having the high number of 48 -bp repeat units.

The relationships between the genotype group and positive or negative symptoms, as well as social function at remission, were also examined. Group II had a lower frequency of negative symptoms and also tended to have higher mean scores for social function than group I. This suggests that schizophrenia in patients with the group II genotype might have a different pathophysiological mechanism than in group I patients. Although the 48-bp repeat polymorphisms of DRD4 have no linkage with schizo-

Table 2. Negative Symptoms in Schizophrenic Patients with Different Repeat Numbers of the DRD4 Gene 48-bp Repeat

\begin{tabular}{|c|c|c|c|c|c|c|}
\hline \multirow[b]{2}{*}{ Symptom } & \multicolumn{2}{|c|}{ Men } & \multicolumn{2}{|c|}{ Women } & \multicolumn{2}{|c|}{ Total } \\
\hline & $\begin{array}{l}\text { Group } \mathrm{I}^{a} \\
(n=22)\end{array}$ & $\begin{array}{l}\text { Group } \mathrm{II}^{b} \\
(n=26)\end{array}$ & $\begin{array}{l}\text { Group } \mathrm{I}^{a} \\
(n=16)\end{array}$ & $\begin{array}{l}\text { Group } \mathrm{II}^{b} \\
(n=16)\end{array}$ & $\begin{array}{l}\text { Group I }{ }^{a} \\
(n=38)\end{array}$ & $\begin{array}{c}\text { Group } \mathrm{II}^{b} \\
(n=42)\end{array}$ \\
\hline Blunt affect & $\begin{array}{l}15^{c} \\
(68.2)\end{array}$ & $\begin{array}{c}9 \\
(34.6)\end{array}$ & $\begin{array}{c}7 \\
(43.8)\end{array}$ & $\begin{array}{c}8 \\
(50.0)\end{array}$ & $\begin{array}{c}22^{d} \\
(57.9)\end{array}$ & $\begin{array}{l}17 \\
(40.5)\end{array}$ \\
\hline Avolition & $\begin{array}{l}16^{c} \\
(72.7)\end{array}$ & $\begin{array}{c}11 \\
(42.3)\end{array}$ & $\begin{array}{l}10 \\
(62.5)\end{array}$ & $\begin{array}{l}10 \\
(62.5)\end{array}$ & $\begin{array}{l}26 \\
(68.4)\end{array}$ & $\begin{array}{l}21 \\
(50.0)\end{array}$ \\
\hline Alogia & $\begin{array}{c}14 \\
(63.6)\end{array}$ & $\begin{array}{c}11 \\
(42.3)\end{array}$ & $\begin{array}{c}9 \\
(56.3)\end{array}$ & $\begin{array}{c}9 \\
(56.3)\end{array}$ & $\begin{array}{l}23 \\
(60.5)\end{array}$ & $\begin{array}{c}20 \\
(47.6)\end{array}$ \\
\hline Asociality & $\begin{array}{c}17^{d} \\
(77.3)\end{array}$ & $\begin{array}{c}14 \\
(53.8)\end{array}$ & $\begin{array}{c}9 \\
(56.3)\end{array}$ & $\begin{array}{l}11 \\
(68.8)\end{array}$ & $\begin{array}{c}26 \\
(68.4)\end{array}$ & $\begin{array}{l}25 \\
(59.5)\end{array}$ \\
\hline Global negative rating & $\begin{array}{c}18^{c} \\
(81.8)\end{array}$ & $\begin{array}{c}14 \\
(53.8)\end{array}$ & $\begin{array}{l}10 \\
(62.5)\end{array}$ & $\begin{array}{c}9 \\
(56.3)\end{array}$ & $\begin{array}{l}28^{d} \\
(73.7)\end{array}$ & $\begin{array}{c}23 \\
(54.8)\end{array}$ \\
\hline
\end{tabular}

${ }^{a}$ Group I genotypes include one allele with two 48-bp repeats and the other with 2, 3, 4, or 6 repeats.

${ }^{b}$ Patients with group II genotype were homozygous for four 48 -bp repeats.

${ }^{c} p<.05$.

$d_{p}<.10$. 
phrenia etiology, they might have pathophysiological meaning in the clinical manifestations of schizophrenic symptoms.

In group II, the higher rate of good neuroleptic response during acute stage treatment was more prominent in men. The lower prevalence of negative symptoms in group II patients was also found only in men. If the 48-bp tandem repeat polymorphisms of the DRD4 gene play a significant role in the pathophysiological mechanism of schizophrenic clinical manifestations, gender has to be considered as a significant mediating variable. The role of gender in schizophrenic clinical manifestations is well known (Goldstein et al 1989; Lewis 1992; Seeman and Lang 1990; Häfner et al 1991). Gender difference in the pathophysiological manifestation of DRD4 polymorphism is therefore an important subject for future investigation.

As dopamine receptors are the main target sites for neuroleptic treatment for the positive symptoms of schizophrenia (Carlsson 1988), polymorphisms of dopamine receptor genes may mediate the response to treatment. Previous studies (Bowers 1991; Chang et al 1993) suggested that a high pretreatment plasma level of homovanillic acid (HVA) was associated with a good neuroleptic response. The relationship between a higher pretreatment HVA level and a higher 48-bp repeat number of the DRD4 gene needs to be explored in the future.

We used patient records and clinical interview data for the assessment of neuroleptic response during acute stage treatment. The interrater reliability of this assessment was satisfactory; however, this is a retrospective approach. A prospective study using an operationalized rating scale should be done. Our study group in Taiwan is currently proceeding with this kind of study (Hwu 1994) using the Positive and Negative Symptom Scale (PANSS) (Kay et al 1986; Cheng et al 1996) for symptom rating.

We did not find a significant difference between groups in the rates of positive symptoms in patients in remission. This is consistent with the results of another study using a different study sample (Lin and Hwu 1993), suggesting that a good neuroleptic response at the acute stage represents a quick neuroleptic response. The positive symptoms subside eventually. This quick neuroleptic response has also been studied in another schizophrenic sample (Hwu and Chang 1994); as in the present study, patients with quick neuroleptic response also had better social function at follow-up.

In summary, we conclude that alleles with a homozygous four 48-bp tandem repeat in the exon 3 of the DRD4 gene are associated with a quick neuroleptic response during treatment at the acute stage, and a lower rate of negative symptoms at remission.

In spite of this conclusive clinical remark, the appropriate biological relevance has to be explored further. The pharmacologic properties of the 48-bp repeat polymorphism of the DRD4 gene were studied in an in vitro experiment (Asghari et al 1994), and the results showed that the binding profiles for all ligands were similar among different forms of the human and rat D4 receptors and repeat deletion mutants. If this study's results were to stand true, the authors would expect that this 48-bp polymorphism might have linkage disequilibrium with other polymorphisms of the DRD4 gene, such as 12-bp deletion/insertion polymorphism of exon 1 , or poly $G$ polymorphism of intron 1 , which have been found to have polymorphism in a Chinese population (Chang et al 1997). Further genotype studies using these two DRD4 gene polymorphisms and haplotype analysis would be a meaningful approach.

This research was supported by grants from the National Science Council, Taiwan (NSC83-0412-B-002-170-M02; 84-2331-B-075-091) and National Health Research Institute, Taiwan (DOH83, 84, 85, 86-HR-306).

\section{References}

American Psychiatric Association (1987): Diagnostic and Statistical Manual of Mental Disorders, 3rd ed rev. Washington, DC: American Psychiatric Press.

Andreasen NC (1984a): Scale for the Assessment of Positive Symptoms. Iowa City, IA: University of Iowa.

Andreasen NC (1984b): Scale for the Assessment of Negative Symptoms. Iowa City, IA: University of Iowa.

Asghari V, Schoots O, Vankats S, Ohara K, Jovanovic V, et al (1994): Dopamine D4 receptor repeat: Analysis of different native and mutant forms of the human and rat genes. Mol Pharmacol 46:364-373.

Barr CL, Kennedy JL, Lichter JB, Van Tol HHM, Wetterberg L, Livak KJ, et al (1993): Alleles at the dopamine D4 receptor locus do not contribute to the genetic susceptibility to schizophrenia in a large Swedish kindred. Am J Med Genet 48:218-222.

Bowers MB (1991): Characteristics of psychotic inpatients with high or low HVA levels at admission. Am J Psychiatry 148:240-243.

Carlsson A (1988): The current status of the dopamine hypothesis of schizophrenia. Neuropsychopharmacology 1:179186.

Chang WH, Hwu HG, Chen TY, Lin SK, Lung FW, Chen H, et al (1993): Plasma homovanillic acid and treatment response in a large group of schizophrenic patients. Schizophr Res 10:259-265.

Chang FM, Ko HC, Lu RB, Pakstis AJ, Kidd KK (1997): The dopamine D4 receptor gene (DRD4) is not associated with alcoholism in three Taiwanese populations: Six polymorphisms tested separately and haplotypes. Biol Psychiatry 74:394-405.

Cheng JJ, Ho H, Chang CJ, Lan SY, Hwu HG (1996): Positive and Negative Syndrome Scale (PANSS): Establishment and 
reliability study of a Mandarin Chinese language version. Chin Psychiatry 96:251-258.

Daniels J, Williams J, Mant R, Asherson P, McGuffin P, Owen MJ (1994): Repeat length variation in the dopamine D4 receptor gene shows no evidence of association with schizophrenia. Am J Med Genet 54:256-258.

Gelernter J, Kennedy JL, Van Tol HHM, Civelli O, Kidd KK (1992): The D4 dopamine receptor (DRD4) maps to distal 11p close to HRAS. Genomics 13:208-210.

Goldstein JM, Tsuang MT, Faraone SV (1989): Gender and schizophrenia: Implications for understanding the heterogeneity of the illness. Psychiatry Res 28:243-253.

Häfner H, Berhrens S, De Vry J, Gattaz WF (1991): An animal model for the effects of estradiol on dopamine-mediated behavior: Implications for sex differences in schizophrenia. Psychiatry Res 38:125-134.

Hong CJ, Lee YL, Sim CB, Hwu HG (in press): Dopamine D4 receptor variants in Chinese sporadic and familial schizophrenics. Am J Med Genet.

Hwu HG (1991): Manual of Psychiatric Diagnosis. Taipei: Publication Committee, College of Medicine, National Taiwan University, pp 352-353.

Hwu HG (1994): Multidimensional psychopathological group research project on schizophrenia. Report of National Health Research Institute, Taiwan (DOH83, 84, 85-HR-306).

Hwu HG, Chang TJ (1994): Quick/slow neuroleptic response in schizophrenia: A validity study. In: Beigel A, Lopez Ibor JJ Jr, Costa e Silva JA, editors. Past, Present and Future of Psychiatry. Singapore: World Scientific, pp 497-501.

Hwu HG, Yang SY (1987): Psychiatrist diagnostic assessment: Establishment and inter-rater reliability. Chin Psychiatry 2:267-278.

Hwu HG, Sunn MC, Chu CH (1987): Community psychiatric rating scale: Inter-rater reliability and applicability. Chin Psychiatry 1:111-122.

Iversen L (1992): Which D4 do you have? Nature 358:109-110.

Kay SR, Opler LA, Fiszbein A (1986): Positive and Negative Syndrome Scale (PANSS): Manual. Toronto: Multi-Health Systems.

Kennedy JL (1994): Prediction of neuroleptic response: Genetic strategies. In: Gaebel W, Awad AG, editors. Prediction of Neuroleptic Treatment Outcome in Schizophrenia. Berlin: Springer-Verlag, pp 147-154.

Kennedy JL, Badri F, Masellis M, Petronis A, Macciardi FM, Van Tol HH, et al (1995): Genetics of dopamine/serotonin system genes and response to clozapine. Psychiatr Genet 5:S100.

Kohn Y, Ebstein RP, Heresco-Levy U, Shapira B, Nemanor L, Gritsenko I, et al (1997): Dopamine D4 receptor gene polymorphisms: Relation to ethnicity, no association with schizophrenia and response to clozapine in Israeli subjects. Eur Neuropsychopharmacol 7:39-43.

Lewis S (1992): Sex and schizophrenia: Vive la difference. $\mathrm{Br} J$ Psychiatry 161:445-450.

Lin CHC, Hwu HG (1993): A study on the clinical correlates of neuroleptic treatment response in schizophrenic patients. Chin Psychiatry 7:97-104.

Macciardi F, Petronis A, Van Tol HH, Marino C, Cavallini MC, Smeraldi E, et al (1994): Analysis of the D4 dopamine receptor gene variant in an Italian schizophrenia kindred. Arch Gen Psychiatry 51:288-293.

Maier W, Schwab S, Hallmayer J, Ertl MA, Minges J, Ackenheil M, et al (1994): Absence of linkage between schizophrenia and the dopamine D4 receptor gene. Psychiatry Res 53:7786.

Meltzer HY (1995): Dopamine, serotonin and glucocorticoids and the psychopathology of schizophrenia. In: Fog R, Gerlach J, Hemmingsen R, editors. Schizophrenia: An Integrated View. Copenhagen: Munksgaard, pp 74-95.

Norusis MJ (1990): SPSS/PC+ Statistics ${ }^{\mathrm{TM}} 4.0$ for the IBM PC/XT/AT and PS/2. Chicago: SPSS Inc.

Petronis A, Macciardi F, Athanassiades A, Paterson AD, Vergas M, Meltzer HY, et al (1995): Association study between the dopamine D4 receptor gene and schizophrenia. Am J Med Genet 60:452-455.

Rao P, Pickar D, Gejman PV, Ram A, Gershon ES, Gelernter J (1994): Allelic variation in the D4 dopamine receptor (DRD4) gene does not predict response to clozapine. Arch Gen Psychiatry 51:912-917.

Rietschel M, Naber D, Oberlander H, Holzbach R, Finmers R, Eggermann K, et al (1996): Efficacy and side-effects of clozapine: Testing for association with allelic variation in the dopamine D4 receptor gene. Neuropsychopharmacology 15: 491-496.

Seeman MV, Lang M (1990: The role of estrogens in schizophrenia gender differences. Schizophr Bull 16:185-194.

Seeman P, Lee T (1975): Antipsychotic drugs: Direct correlation between clinical potency and presynaptic action on dopamine neurons. Science 188:1217-1219.

Seeman P, Niznik IIR, Guan HC, Booth G, Ulpian C (1989): Link between D1 and D2 dopamine receptors is reduced in schizophrenia and Huntington disease brain. Proc Natl Acad Sci USA 86:10156-10160.

Seeman P, Guan HC, Van Tol HHM (1993): Dopamine D4 receptors elevated in schizophrenia. Nature 365:441-445.

Shaikh S, Collier D, Kerwin RW, Pilowsky LS, Gill M, Xu WM, et al (1993): Dopamine D4 receptor subtypes and response to clozapine. Lancet 341:116.

Shaikh S, Gill M, Owen M, Asherson P, McGuffin P, Nanko S, et al (1994): Failure to find linkage between a functional polymorphism in the dopamine D4 receptor gene and schizophrenia. Am J Med Genet 54:8-11.

Shaikh S, Collier DA, Sham P, Pilowsky L, Sharma T, Lin LK, et al (1995): Analysis of clozapine response and polymorphisms of the dopamine D4 receptor gene (DRD4) in schizophrenic patients. Am J Med Genet 60:541-545.

Van Tol HHM, Bunzow JR, Guan HC, Sunahara RK, Seeman P, Niznik HB, et al (1991): Cloning of the gene for human D4 receptor with high affinity for the antipsychotic clozapine. Nature 350:610-619. 